EXPERIMENTAL STUDY

\title{
Uncoupling protein 2 mRNA expression and respiratory parameters in Kupffer cells isolated from euthyroid and hyperthyroid rat livers
}

\author{
A Voci, I Demori, A T Franzi ${ }^{1}$, E Fugassa, F Goglia ${ }^{2}$ and A Lanni ${ }^{3}$ \\ Dipartimento di Biologia Sperimentale. Ambientale ed Applicata (DIBISAA), Sez. Fisiologia Generale e Comparata, Università degli Studi di Genova, \\ C.so Europa 26, I-16132 Genova, ${ }^{1}$ Dipartimento di Medicina Sperimentale (DIMES), Sez. Anatomia Umana, Via De Toni 14, I-16132 Genova, ${ }^{2}$ Facoltà \\ di Scienze, Università degli Studi del Sannio, Via Port'Arsa 11, I-82100 Benevento, and ${ }^{3}$ Dipartimento di Scienze della Vita, Seconda Università degli \\ Studi di Napoli, Via Vivaldi 43, I-81100 Caserta, Italy \\ (Correspondence should be addressed to A Lanni, Dipartimento di Scienze della Vita, Seconda Università degli Studi di Napoli, Via Vivaldi 43 , I-81100 \\ Caserta, Italy; Email: antonia.lanni@unina2.it)
}

\begin{abstract}
Objective: The levels of uncoupling protein 2 (UCP2) mRNA and determinants of respiration (ATP synthesis, proton leak and non-mitochondrial respiration) were evaluated in Kupffer cells isolated from the livers of normal euthyroid, acute hyperthyroid and chronic hyperthyroid rats.

Methods: After liver perfusion, Kupffer cells were purified by density-gradient centrifugation followed by counterflow centrifugal elutriation. UCP2 mRNA levels were measured by Northern blot and respiratory parameters by polarographic method.

Results: In cells isolated from hyperthyroid (tri-iodothyronine $\left(\mathrm{T}_{3}\right)$-treated) rats, the effect of $\mathrm{T}_{3}$ treatment on the UCP2 mRNA level varied: it was more than doubled $(P<0.05)$ in acutely $\mathrm{T}_{3^{-}}$ treated rats but, after chronic (3-week) $\mathrm{T}_{3}$ treatment, it was only 30\% (not statistically significant) above the control (euthyroid) level. In Kupffer cells from the livers of chronic hyperthyroid rats, we observed an increase in total respiration rate, with an increase in the percentage attributable to the proton leak and a corresponding decrease in the percentage attributable to ATP synthesis (no alteration was observed in the percentage attributable to non-mitochondrial respiration). In the acute hyperthyroid rats, no significant differences were observed in any of the respiratory parameters, although they all tended to increase.

Conclusion: These data are indicative of a possible uncoupling effect of UCP2 in Kupffer cells. $\mathrm{T}_{3}$, by enhancing the expression of UCP2, could play a role in the energy homeostasis of these cells.
\end{abstract}

European Journal of Endocrinology 145 317-322

\section{Introduction}

The liver is one of the main organs used to study the effects of thyroid hormones on energy metabolism and, as parenchymal cells constitute the bulk of the liver, hepatocytes have been used almost exclusively in such studies. The studies performed on these cells have permitted a clear characterization of their metabolic parameters as well as of the effects exerted on them by hormones and their role in the control of energy expenditure $(1,2)$. The liver contributes both to coldinduced thermogenesis and to the calorigenic effects of thyroid hormones. Although it is assumed that both cold and thyroid hormones induce an uncoupling of liver mitochondria $(3,4)$, the cellular mechanisms underlying these effects remain obscure. Actually, the molecular determinants of energy expenditure are, at present, largely unknown. However, besides the uncoupling protein (UCP) present in brown adipose tissue (termed UCP1), three UCP homologues have been identified: these are either widely expressed throughout the body (UCP2) $(5,6)$ or expressed abundantly in skeletal muscle (UCP3) $(7,8)$ or brain (UCP4) $(9,10)$. Because of their location, UCP2 and UCP 3 may play important roles in the regulation of energy balance (11-14). Other important evidence pointing in this direction comes from reports that tri-iodothyronine $\left(\mathrm{T}_{3}\right)$ stimulates the expression of the mRNAs for UCP1 (15), UCP2 (16-19) and UCP3 $(11,18,20,21)$. At least in the case UCP1, this stimulation seems to reflect a direct, not a permissive role (15). The functional properties of these new uncoupling proteins, however, are still largely unknown.

The family of uncoupling proteins is thought to play important roles in the regulation of energy metabolism by uncoupling the respiratory chain reactions from ATP synthesis. However, an uncoupling effect of UCP2 and UCP3 has been shown predominantly when they 
are ectopically expressed in yeast strains or in transformed mammalian cells (for review, see 22). When they are eutopically expressed, it is difficult to establish a clear correlation between the presence of UCP and uncoupling activity, even if, at least for UCP3, it has been recently shown that (a) a good correlation exists between mRNA expression and mitochondrial coupling in rat skeletal muscle (21), (b) skeletal muscle mitochondria lacking UCP3 show better coupling than wild-type mitochondria (23) and (c) mitochondria overexpressing UCP3 are more uncoupled than wildtype ones (24). No similar evidence exists for UCP2.

It has recently been shown that UCP2 mRNA is expressed in the liver only in non-parenchymal cells (25), such as Kupffer cells, and that it is expressed only in transformed, not in normal hepatocytes (26). In Kupffer cells, in contrast to the situation in hepatocytes, few studies have been performed on metabolic parameters and their regulation by thyroid hormones. In view of the above considerations, and in order to gain greater insight into the role of UCP2, we studied its expression in Kupffer cells obtained from rats in various thyroid states and we also measured respiratory parameters in the same cells. As far as we know, the role of $\mathrm{T}_{3}$ on metabolic parameters in isolated Kupffer cells has not previously been investigated. In the present study, the effects of $\mathrm{T}_{3}$ on both the UCP2 mRNA level and determinants of respiration (ATP synthesis, proton leak and non-mitochondrial respiration) were evaluated in isolated Kupffer cells.

\section{Materials and methods}

\section{Treatment of rats}

Male Wistar rats (220-230 g) were kept under artificial lighting (12 h light:12 $\mathrm{h}$ darkness) in a temperature-controlled room at $28{ }^{\circ} \mathrm{C}$. They were allowed standard laboratory chow and water ad libitum. Acute hyperthyroidism was induced in euthyroid rats by i.p. injection of $\mathrm{T}_{3}(25 \mu \mathrm{g} / 100 \mathrm{~g}$ body weight (b.w.)) $48 \mathrm{~h}$ before they were killed. Chronic hyperthyroidism was induced in euthyroid rats by daily i.p. injection of $15 \mu \mathrm{g} \mathrm{T} / 100 \mathrm{~g}$ b.w. for 3 weeks. Euthyroid rat controls were injected with saline.

\section{Resting metabolism and thyroid hormone levels in serum}

Resting metabolism was measured by indirect calorimetry, as previously reported (27) and thyroid hormone serum levels were measured by radioimmunoassay (Becton-Dickinson, Orangenburg, NJ, USA).

\section{Cell preparation}

Kupffer cells were isolated from euthyroid and hyperthyroid male Wistar rats as described elsewhere
(28, 29). Briefly, the liver was first perfused in situ through the portal vein with a calcium-deprived Krebs-Ringer buffer (KRB). Hepatocytes were digested with $0.1 \%$ pronase in $\mathrm{KRB}$ for $5 \mathrm{~min}$ at $37^{\circ} \mathrm{C}$ following perfusion with KRB containing $0.04 \%$ collagenase and $0.02 \%$ pronase for $30 \mathrm{~min}$ at $37^{\circ} \mathrm{C}$ under recirculating conditions. The cell suspension was then incubated for 20 min under magnetic stirring at $37{ }^{\circ} \mathrm{C}$ with KRB containing $0.03 \%$ collagenase, $0.01 \%$ pronase and $0.001 \%$ DNAse I at $\mathrm{pH}$ 7.4. The remaining nonparenchymal cells were centrifuged for $10 \mathrm{~min}$ at 400 g. Kupffer cells were purified by single-layer $15.7 \%$ Nycodenz (Sigma-Aldrich, Milan, Italy) density-gradient centrifugation, followed by counterflow centrifugal elutriation in a JE 6B rotor (Beckman, Palo Alto, CA, USA). The viability and number of Kupffer cells in the resulting suspension were determined by the Trypan blue exclusion test. The cell preparation was characterized by immunoreactivity with the monoclonal antibody ED2 (30). More than $90 \%$ of the cells were positive when stained with this antibody.

\section{Measurement of respiration rate}

Kupffer cells were incubated in a medium containing $125 \mathrm{mmol} / \mathrm{l} \mathrm{NaCl}, 5.2 \mathrm{mmol} / \mathrm{l} \mathrm{KCl}, 1 \mathrm{mmol} / \mathrm{l} \mathrm{Na}_{2} \mathrm{PO}_{4}$, $0.5 \mathrm{mmol} / \mathrm{l} \mathrm{CaCl}, 10 \mathrm{mmol} / \mathrm{l}$ glucose and $10 \mathrm{mmol} / \mathrm{l}$ Hepes, $\mathrm{pH}$ 7.3. For all experiments, cells were incubated at $5 \times 10^{6}$ cells $/ \mathrm{ml}$ at $37^{\circ} \mathrm{C}$. Oxygen consumption was measured using a Clark-type oxygen electrode. The cell suspension in the Perspex incubation chamber of the electrode was magnetically stirred and thermostatically maintained at $37^{\circ} \mathrm{C}$. The non-mitochondrial oxygen consumption rate was measured in the presence of antimycin $(0.5 \mu \mathrm{g} / \mathrm{ml})$. The upper limit of the respiration driving the proton leak was taken as the oxygen consumption rate in the presence of oligomycin $(10 \mu \mathrm{g} / \mathrm{ml})$ minus the oxygen consumption rate in the presence of antimycin. The lower limit of the respiration driving ATP synthesis was taken as the control oxygen consumption rate minus the oxygen consumption rate in the presence of oligomycin (31, $32)$.

\section{RNA isolation and Northern blotting}

Total RNA was purified from isolated Kupffer cells using acid guanidinium thyocyanate-phenol-chloroform extraction (33). RNA was quantified by measuring absorbance at $260 \mathrm{~nm}$. Samples were stored at $-80{ }^{\circ} \mathrm{C}$ until used. For Northern blot, $20 \mu \mathrm{g}$ total RNA were separated on $1 \%$ agarose gel containing $2.2 \mathrm{~mol} / \mathrm{l}$ formaldehyde in $20 \mathrm{mmol} / \mathrm{l} \mathrm{MOPS}$, $\mathrm{pH} 7.0,5 \mathrm{mmol} / \mathrm{l}$ sodium acetate and $1 \mathrm{mmol} / \mathrm{l}$ disodium EDTA. Ethidium bromide was added to electrophoresed samples so that RNA integrity and loading could be verified. RNA was transferred onto nylon membranes with $20 \times$ SSC $(1 \times \mathrm{SSC}=150 \mathrm{mmol} / \mathrm{l} \mathrm{NaCl}$ and $15 \mathrm{mmol} / \mathrm{l}$ sodium 
citrate, $\mathrm{pH}$ 7.0). To detect specific mRNA, we used a $900 \mathrm{bp}$ probe derived from murine UCP2 cDNA (GenBank accession number U69135) (5) which was labelled with ${ }^{32} \mathrm{P}$ using a random priming system. Hybridization and washing were carried out as previously described (34). To ensure even loading, the membranes were stripped and rehybridized with a rat $18 \mathrm{~S}$ rDNA probe provided by Dr I G Wool (35). The signal intensity of the autoradiograms was quantified densitometrically using a Scion Image PC Software package (Scion Corporation, USA). Arbitrary densitometric units were normalized with respect to $18 \mathrm{~S}$ and expressed as a percentage of the control value.

\section{Statistical analysis}

Results are expressed as means \pm S.E. The statistical significance of differences between groups was determined by a one-way analysis of variance followed by a Student-Newman-Keuls test.

\section{Results}

\section{Body weight, serum levels of thyroid hormones and resting metabolism (RM) in euthyroid and chronic hyperthyroid rats}

At the beginning of the experiments, the rats weighed $200 \pm 12 \mathrm{~g}$. At the end of the treatment, they weighed $300 \pm 20 \mathrm{~g}$. No significant differences were observed between euthyroid and hyperthyroid rats. To make sure that the rats were really hyperthyroid, we measured RM and $\mathrm{T}_{3}$ serum levels in euthyroid and hyperthyroid rats (Table 1). When compared with the euthyroid rats, the acutely and chronically $\mathrm{T}_{3}$-treated rats had RM levels 23\% and $67 \%$ higher respectively. The free and total $\mathrm{T}_{3}$ serum levels were, respectively, 2.5 times and 4.5 times the euthyroid level in chronically $\mathrm{T}_{3}$-treated rats; the corresponding figures were $75 \%$ and $154 \%$, respectively, in acutely $\mathrm{T}_{3}$-treated rats. These data are in accordance with the $\mathrm{T}_{3}$-treated animals being in the expected hyperthyroid state, even if the chronically $\mathrm{T}_{3}$-treated rats showed higher values than the acutely $\mathrm{T}_{3}$-treated ones.

Table 1 Resting metabolic rate and serum levels of thyroid hormones in euthyroid (C), acute hyperthyroid (T3-A) and chronic hyperthyroid rats (T3-C). Values are the mean \pm S.E. of three to four independent experiments.

\begin{tabular}{lccc}
\hline & C & T3-A & T3-C \\
\hline $\begin{array}{c}\text { Total T } \\
(\mathrm{nmol} / \mathrm{l})\end{array}$ & $1.22 \pm 0.08^{\mathrm{a}}$ & $3.10 \pm 0.34^{\mathrm{b}}$ & $5.82 \pm 0.63^{\mathrm{c}}$ \\
$\begin{array}{c}\text { Free } \mathrm{T}_{3} \\
(\mathrm{pmol} / \mathrm{l})\end{array}$ & $5.81 \pm 0.52^{\mathrm{a}}$ & $10.2 \pm 0.89^{\mathrm{b}}$ & $14.91 \pm 1.42^{\mathrm{c}}$ \\
$\begin{array}{c}\text { Resting metabolic rate } \\
\left(1 \mathrm{O}_{2} / \mathrm{h}^{\mathrm{k}} / \mathrm{kg}^{0.75} \text { b.w.) }\right.\end{array}$ & $1.40 \pm 0.06^{\mathrm{a}}$ & $1.73 \pm 0.09^{\mathrm{b}}$ & $2.34 \pm 0.11^{\mathrm{c}}$ \\
\hline
\end{tabular}

Values within a given row labelled with different letters are significantly different $(P<0.05)$ from each other.

\section{UCP2 mRNA levels in Kupffer cells isolated from euthyroid and hyperthyroid rats}

As shown in Fig. 1, UCP2 mRNA was clearly detected in Kupffer cells from control euthyroid animals. In cells isolated from hyperthyroid rats, the UCP2 mRNA levels showed evidence that the effect depends on the duration of $\mathrm{T}_{3}$ treatment. The UCP2 mRNA level was more than doubled in the acutely $\mathrm{T}_{3}$-treated rats. However, the level in the chronic $\mathrm{T}_{3}$-treated group, although tending to be higher than in control animals (+30\%, not significant), was significantly lower than in the acute hyperthyroid rats. UCP2 mRNA was not expressed in euthyroid parenchymal cells and its expression was not induced by either of the $T_{3}$ treatments (data not shown).
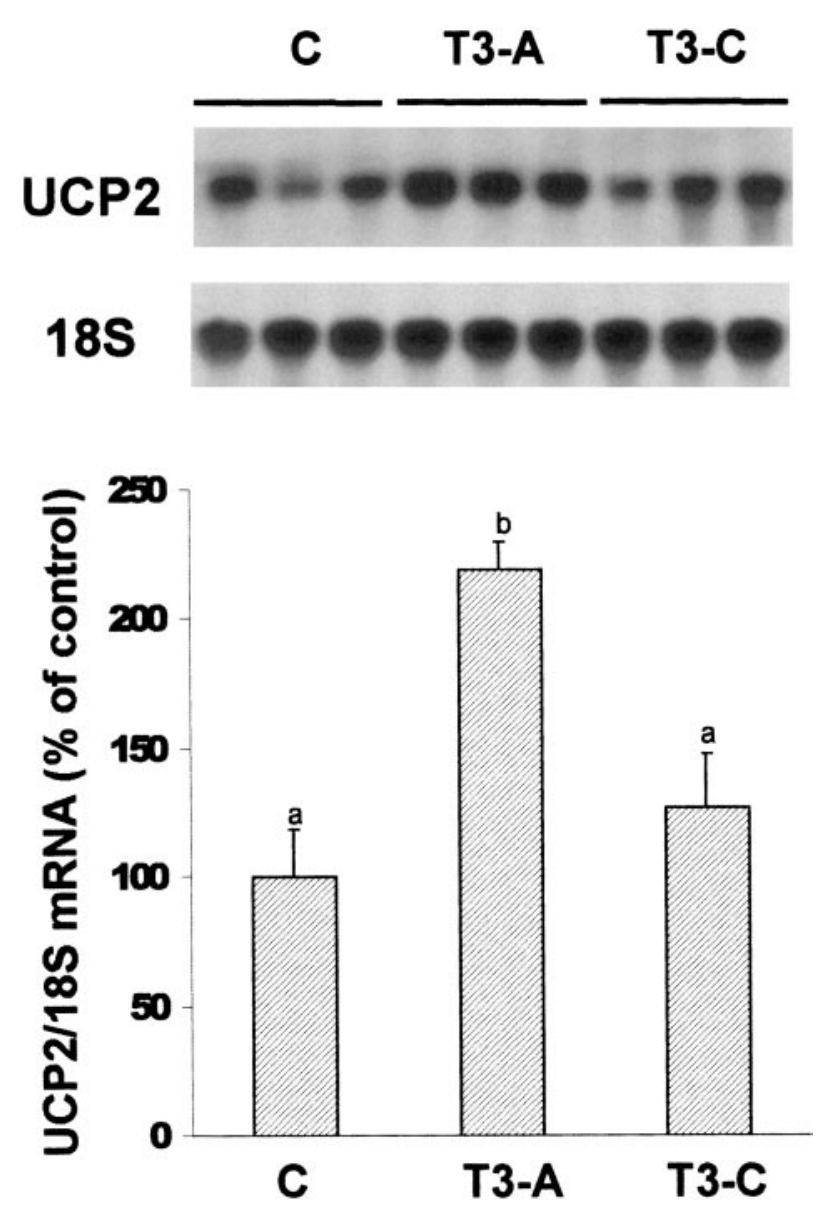

Figure 1 (Upper panel) Expression levels of UCP2 mRNA in Kupffer cells isolated from normal euthyroid rats (C), acutely treated hyperthyroid rats (T3-A) and chronically treated

hyperthyroid rats (T3-C). (Lower panel) Hybridization with an 18Sderived oligonucleotide. Values (mean of three experiments) are expressed as a percentage of the UCP2 to $18 \mathrm{~S}$ ratio obtained in C (normal euthyroid rats). Columns labelled with different letters are significantly different $(P<0.05)$ from each other. 
Table 2 Respiratory parameters in Kupffer cells isolated from euthyroid (C), acute hyperthyroid (T3-A) and chronic hyperthyroid rats (T3-C). Values are the mean \pm S.E. from three to four different Kupffer cell preparations.

\begin{tabular}{|c|c|c|c|}
\hline \multirow[b]{3}{*}{$\begin{array}{l}\text { Total respiration rate } \\
\text { Non-mitochondrial respiration } \\
\text { Proton leak } \\
\text { ATP synthesis }\end{array}$} & \multicolumn{3}{|c|}{ Respiration rates (natoms oxygen $/ \mathrm{min} / 5 \times 10^{6}$ cells) } \\
\hline & $\mathrm{C}$ & T3-A & T3-C \\
\hline & $\begin{array}{r}6.38 \pm 0.96^{\mathrm{a}} \\
1.0 \pm 0.09^{\mathrm{a}} \\
0.51 \pm 0.12^{\mathrm{a}} \\
4.87 \pm 0.82^{\mathrm{a}}\end{array}$ & $\begin{array}{l}8.79 \pm 0.18^{\mathrm{a}} \\
1.60 \pm 0.21^{\mathrm{ab}} \\
0.84 \pm 0.08^{\mathrm{a}} \\
6.16 \pm 0.29^{\mathrm{a}}\end{array}$ & $\begin{array}{r}12.26 \pm 1.30^{b} \\
2.21 \pm 0.30^{b} \\
1.93 \pm 0.21^{b} \\
8.21 \pm 1.28^{a}\end{array}$ \\
\hline & \multicolumn{3}{|c|}{$\begin{array}{l}\text { Percentage of Kupffer cell respiration rate required to drive } \\
\text { the following processes }\end{array}$} \\
\hline & $\mathrm{C}$ & T3-A & T3-C \\
\hline $\begin{array}{l}\text { Non-mitochondrial respiration } \\
\text { Proton leak } \\
\text { ATP synthesis }\end{array}$ & $\begin{array}{r}15.7^{\mathrm{a}} \\
8.0^{\mathrm{a}} \\
76.0^{\mathrm{a}}\end{array}$ & $\begin{array}{r}18.0^{\mathrm{a}} \\
9.5^{\mathrm{a}} \\
7.0^{\mathrm{a}}\end{array}$ & $\begin{array}{l}17.3^{\mathrm{a}} \\
15.7^{\mathrm{b}} \\
67.0^{\mathrm{a}}\end{array}$ \\
\hline
\end{tabular}

Values within a given row labelled with different letters are significantly different $(P<0.05)$ from each other.

\section{Respiratory parameters in Kupffer cells isolated from euthyroid and chronic hyperthyroid rats}

As shown in Table 2, the respiratory parameters were more or less doubled in cells isolated from chronic hyperthyroid rats, except for respiration due to the proton leak, which was almost quadrupled. In percentage terms (Table 2), the proton leak accounted for $8 \%$ of Kupffer-cell respiration in cells from euthyroid rats but for $16 \%$ in cells from chronic hyperthyroid ones. Accordingly, since an insignificant alteration was observed in the respiration rate due to non-mitochondrial respiration, the percentage of respiration attributable to ATP synthesis varied in the opposite way: it represented $76 \%$ and $67 \%$ of total respiration in the euthyroid and chronic hyperthyroid rats respectively. Cells isolated from acute hyperthyroid rats showed consistent, even if statistically insignificant, increases in the values of the measured respiratory parameters (between 26-28\% and 60-64\%).

\section{Discussion}

In the present study, UCP2 mRNA was clearly detected in Kupffer cells isolated from euthyroid rats, confirming a previous report from Ricquier's group (25). Our data also show that the UCP2 mRNA level in the Kupffer cell is clearly affected by $\mathrm{T}_{3}$, although this effect depends on the duration of the treatment. In fact, $48 \mathrm{~h}$ after a single injection of $\mathrm{T}_{3}$ the UCP2 mRNA level was more than doubled, but the increase above the euthyroid level was significantly smaller after chronic $\mathrm{T}_{3}$ treatment. These data are not surprising since other authors have already shown a similar two-phase regulation of UCP 3 by cold and of UCP 2 by bezafibrate $(36,37)$.
An interesting controversial question concerning UCP2 is its capacity to uncouple respiration. When mouse UCP2 is expressed in yeast cells it can certainly uncouple respiration (5) but the idea of its having a role as an uncoupler has received both support and opposition (for review, see 22). The discrepancies may be due to the methods used to measure the leak in vitro, where several factors (such as mitochondrial purity, the presence of fatty acids and the presence or absence of regulatory factors) may influence the assay. Under our conditions, however, these factors were less relevant because we measured the respiratory determinants in intact cells. In the euthyroid state, the percentage values we obtained for respiratory determinants (proton leak, non-mitochondrial respiration and ATP synthesis) are close to the range of values reported for hepatocytes (38). However, by comparison with hepatocytes, Kupffer cells show a lower degree of leakage ( $8 \%$ in Kupffer cells and 19-25\% in hepatocytes) and use a higher percentage of respiration to drive ATP synthesis (76\% in Kupffer cells and $67 \%$ in hepatocytes). We could argue that Kupffer-cell mitochondria, in spite of the presence of an uncoupling protein, are better coupled than hepatocytes. However, following the recent identification of a new member of the uncoupling protein family (termed UCP5) in various cells including hepatocytes (39), the contradiction may prove to be more apparent than real.

The precise function and biological importance of UCP 2 and its regulation by $\mathrm{T}_{3}$ in Kupffer cells is not clear at the moment. In this study, we have tried to make a contribution to the clarification of this problem by correlating the $\mathrm{T}_{3}$-induced UCP 2 mRNA levels with the values of the mitochondrial respiratory parameters. Under our conditions, we found that, in Kupffer cells, accompanying the $\mathrm{T}_{3}$-induced increase in the UCP2 mRNA level there are increases in mitochondrial 
respiratory parameters, with the increase in the contribution made by the proton leak to total cellular respiration being the most marked. However, although in chronically treated rats the level of the mRNA was lower than in acutely treated rats, the increase in the contribution made by the proton leak to total respiration was significantly greater. A possible explanation could be that in acutely treated rats, but not in chronically treated ones, the increase in the UCP2 transcript is not reflected by a parallel increase in the concentration of the protein in the mitochondria. It would be very interesting to check this directly but at the moment there are unfortunately no UCP2 antibodies that will unequivocally detect UCP2 protein.

If, in the chronically treated rats, in spite of a lower level of UCP2 mRNA (compared with the acutely treated rats), there is indeed an increase in the expression of the protein, the results presented here would be in agreement with a possible uncoupling effect of UCP 2 and could suggest a role for these cells in liver thermogenesis. The contribution made by liver thermogenesis to the resting metabolic rate amounts to about $10-20 \%$, but little attention has been paid to the role of the various cell types present in the liver, since the contribution made by cells other than hepatocytes to energy metabolism has been assumed to be small. Indeed, mitochondria from Kupffer cells account for a small proportion of total liver mitochondria (40). However, apart from a general, albeit weak, thermoregulatory role, the induction of UCP 2 in Kupffer cells may be involved in a cell-specific mechanism of thermoregulation (important because macrophages are involved in inflammatory processes). Other roles are also possible, even if they must remain speculative at the moment. For example, it is noteworthy that UCP2 is expressed in all macrophage-containing tissues, such as spleen, thymus and bone marrow (5). Macrophages, including Kupffer cells, usually respond to stimuli with particular metabolic responses, such as the 'oxygen burst' during phagocytosis (for review, see 41 ). This process generates large quantities of superoxide, a species that is strongly antimicrobial but may also cause damage and contribute to inflammatory tissue injury. As an increase in the expression of UCP2 is associated with a decrease in the production of reactive oxygen species by mitochondria (42), the induction of UCP 2 by $\mathrm{T}_{3}$ in Kupffer cells may represent an antioxidant defence mechanism in these cells.

In conclusion, the results presented here suggest that $\mathrm{T}_{3}$, by enhancing the expression of UCP2, may play a role in the Kupffer cell's energy homeostasis. However, further investigations are needed before we can be clear about the physiological implications of this effect.

\section{Acknowledgements}

We are grateful to Valter Capicchioni and Antonella Strangio for excellent technical assistance. This work was supported by research grants from MURST (COFIN 2000, MM05C48114), Rome, Italy.

\section{References}

1 Berry MN, Clark DG, Grivell ER \& Wallace PG. The calorigenic nature of hepatic ketogenesis: an explanation for the stimulation of respiration induced by fatty substrates. European Journal of Biochemistry 1983131 205-214.

2 Brand MD \& Murphy MP. Control of electron flux through the respiratory chain in mitochondria and cells. Biological Reviews 198762 141-193.

3 Goglia F, Liverini G, Lanni A, Iossa S \& Barletta A. Light mitochondria and cellular thermogenesis. Biochemical and Biophysical Research Communications 1988151 1241-1249.

4 Lanni A, Martins R, Ambid L \& Goglia F. Liver and brown fat mitochondrial response to cold in the garden dormouse (Eliomys quercinus). Comparative Biochemistry and Physiology 1990 97B 809-813.

5 Fleury C, Neverova M, Collins S, Raimbault S, Champigny O, Levi-Meyrueis C et al. Uncoupling protein-2: a novel gene linked to obesity and hyperinsulinemia. Nature Genetics $199713269-$ 272.

6 Gimeno RE, Dembski M, Weng X, Deng N, Shyjan AW, Gimeno CJ et al. Cloning and characterization of an uncoupling protein homologue. Diabetes 199746 900-906.

7 Boss O. Samec S, Paoloni-Giacobino A, Rossier C, Dulloo AG, Seydoux J et al. Uncoupling protein-3: a new member of the mitochondrial carrier family with tissue-specific expression. FEBS Letters 1997408 29-42.

8 Vidal-Puig A, Solanes G, Grujic D, Flier JS \& Lowell BB. UCP3: an uncoupling protein homologue expressed preferentially and abundantly in skeletal muscle and brown adipose tissue. Biochemical and Biophysical Research Communications 1997235 79-82.

9 Sanchis D, Fleury C, Chomiki N, Goubern M, Huang OL, Neverova $\mathrm{M}$ et al. BMCP1, a novel mitochondrial carrier with high expression in the central nervous system of humans and rodents, and respiration uncoupling activity in recombinant yeast. Journal of Biological Chemistry 1998273 34611-34615.

10 Mao WG, Yu XX, Zhong A, Li WL, Brush J, Sherwood SW et al. UCP4, a novel brain-specific mitochondrial protein that reduces membrane potential in mammalian cells. FEBS Letters 1999 $443326-330$.

11 Gong DW, He Y, Karas M \& Reitman M. Uncoupling protein-3 is a mediator of thermogenesis regulated by thyroid hormone, $\beta 3$ adrenergic agonists, and leptin. Journal of Biological Chemistry 1997272 24129-24132.

12 Larkin S, Mull E, Miao W, Pittner R, Albrandt K, Moore C et al. Regulation of the third member of the uncoupling protein family, UCP3, by cold and thyroid hormone. Biochemical and Biophysical Research Communications 1997240 222-227.

13 Millet L, Vidal H, Andreelli F, Larrouy D, Riou JP, Ricquier D et al. Increased uncoupling protein-2 and -3 mRNA expression during fasting in obese and lean humans. Journal of Clinical Investigation $19971002665-2670$.

14 Boss O, Samec S, Kuhne F, Bijienga P, Assimacopoulos-Jeannet F, Seydoux $\mathrm{J}$ et al. Uncoupling protein-3 expression in rodent skeletal muscle is modulated by food intake but not by changes in environmental temperature. Journal of Biological Chemistry 1998 273 5-8.

15 Branco M, Ribeiro M, Negrao N \& Bianco AC. 3,5,3'Triiodothyronine actively stimulates UCP in brown fat under minimal sympathetic activity. American Journal of Physiology 1999276 E179-E187.

16 Lanni A, De Felice M, Lombardi A, Moreno M, Fleury C, Ricquier D et al. Induction of UCP2 mRNA by thyroid hormones in rat heart. FEBS Letters $1997 \mathbf{4 1 8} 171-174$. 
17 Masaki T, Yoshimatsu H, Kakuma T, Hidaka S, Kurokawa M \& Sakata T. Enhanced expression of uncoupling protein 2 gene in rat white adipose tissue and skeletal muscle following chronic treatment with thyroid hormone. FEBS Letters $1997 \mathbf{4 1 8} 323-$ 326.

18 Jekabson MB, Gregoire FM, Schonfeld-Warden NA, Warden CH \& Horwitz BA. T3 stimulates resting metabolism and UCP-2 and UCP-3 mRNA but not nonphosphorylating mitochondrial respiration in mice. American Journal of Physiology 1999277 E380-E389.

19 Masaki T, Yoshimatsu H \& Sakata T. Expression of rat uncoupling protein family mRNA levels by chronic treatment with thyroid hormone. International Journal of Obesity $2000 \mathbf{2 4}$ (Suppl 2) S162-S164.

20 Cusin I, Rouru J, Visser T, Burger AG \& Rohner-Jeanrenaud F. Involvment of thyroid hormones in the effect of intracerebroventricular leptin infusion on uncoupling protein-3 expression in rat muscle. Diabetes 200049 1101-1105.

21 Lanni A, Beneduce L, Lombardi A, Moreno M, Boss O, Muzzin P et al. Expression of uncoupling protein-3 and mitochondrial activity in the transition from hypothyroid to hyperthyroid state in rat skeletal muscle. FEBS Letters $1999 \mathbf{4 4 4} 250-254$.

22 Ricquier D \& Bouillard F. The uncoupling protein homologues: UCP1, UCP2, UCP3, StUCP and AtUCP. Biochemical Journal 2000 $345161-179$.

23 Vidal-Puig AJ, Grujic D, Zhang C-Y, Hagen T, Boss O, Ido Y et al. Energy metabolism in uncoupling gene knockout mice. Journal of Biological Chemistry 2000275 16258-16266.

24 Clapham JC, Arch JRS, Chapman H, Haynes A, Lister C, Moore GB et al. Mice overexpressing human uncoupling protein-3 in skeletal muscle are hyperphagic and lean. Nature $2000 \mathbf{4 0 6}$ 415-418.

25 Larrouy D, Laharrague P, Carrera G, Viguerie-Bascands N, LeviMeyrueis C, Fleury C et al. Kupffer cells are a dominant site of uncoupling protein 2 expression in rat liver. Biochemical and Biophysical Research Communications 1997235 760-764.

26 Carretero MV, Torres L, Latasa U, Garcia-Trevijano ER, Prieto J, Mato JM et al. Transformed but not normal hepatocytes express UCP2. FEBS Letters 1998439 55-58.

27 Lanni A, Moreno M, Lombardi A \& Goglia F. Calorigenic effect of diiodothyronine in the rat. Journal of Physiology $1996 \mathbf{4 9 4} 831$ 837.

28 Knook DL \& Sleyster EC. Separation of Kupffer cells and endothelian cells of the rat liver by centrifugal elutriation. Experimental Cell Research 197699 444-449.

29 Schmitz F, Bresciani R, Hartmann H \& Braulke T. Effect of insulin-like factor II on uptake of arylsulfatase A by cultured rat hepatocytes and Kupffer cells. Journal of Hepatology 199522 356-363.
30 Dijkstra CD, Dopp EA, Joling P \& Kraal G. The heterogeneity of mononuclear phagocytes in lymphoid organs: distinct macrophage subpopulations in the rat recognized by monoclonal antibodies ED1, ED2 and ED3. Immunology 1985 54 589-599.

31 Brand MD. The proton leak across the mitochondrial membrane. Biochimica et Biophysica Acta 19901018 128-133.

32 Nobes CD, Brown GC, Olive PN \& Brand MD. Non-ohmic proton conductance of the mitochondrial inner membrane in hepatocyte. Journal of Biological Chemistry 1990265 12903-12909.

33 Chomczynski P \& Sacchi N. Single-step method of RNA isolation by acid guanidinium thiocyanate-phenol-chloroform. Analytical Biochemistry $1987 \mathbf{1 6 2} 156-159$.

34 Demori I, Balocco S, Voci A \& Fugassa E. Increased insulin-like growth factor binding protein-4 expression after partial hepatectomy. American Journal of Physiology 2000278 G384-G389.

35 Chan L, Gutell R, Noller HF \& Wool IG. The nucleotide sequence of a rat $18 \mathrm{~S}$ ribosomal ribonucleic acid gene and a proposal for the secondary structure of $18 \mathrm{~S}$ ribosomal ribonucleic acid. Journal of Biological Chemistry $1984259224-230$.

36 Lin B, Coughlin S \& Pilch PF. Bidirectional regulation of uncoupling protein-3 and GLUT-4 mRNA in skeletal muscle by cold. American Journal of Physiology 1998275 E386-E391.

37 Murase T, Kondo H, Hase T, Tokimitsu I \& Saito M. Abundant expression of uncoupling protein-2 in the small intestine: upregulation by dietary fish oil and fibrates. Biochimica and Biophysica Acta 20011530 15-22.

38 Brand MD, Couture P, Else PL, Withers KW \& Hulbert AJ. Evolution of energy metabolism. Biochemical Journal $1991 \mathbf{2 7 5}$ 81-86.

39 Yu XX, Mao W, Zhong A, Schow P, Brush J, Sherwood SW et al. Characterization of novel UCP5/BMCP1 isoform and differential regulation of UCP4 and UCP5 expression through dietary or temperature manipulation. FASEB Journal $2000 \mathbf{1 4} 1611-$ 1618.

40 Blouin A, Bolender RP \& Weibel ER. Distribution of organelles and membranes between hepatocytes and non hepatocytes in the rat liver parenchyma. Journal of Cell Biology $1977 \mathbf{7 2}$ 441-455.

41 Wake K, Decker K, Kirn A, Knook DL, McCuskey RS, Bowens L et al. Cell biology and kinetics of Kupffer cells in the liver. International Review of Cytology 1989118 173-229.

42 Nègre-Salvayre A, Hirtz C, Carrera G, Cazenave R, Troly M, Salvayre $\mathrm{R}$ et al. A role of uncoupling protein-2 as a regulator of mitochondrial hydrogen peroxide generation. FASEB Journal $199711809-815$.

Received 11 December 2000

Accepted 4 May 2001 